\title{
The Effects of Fair Value on the Matching of Revenues and Expenses: The Case of Asset Revaluations
}

\author{
Fábio Moraes da Costa \\ Fucape Business School \\ Vitória, Brazil \\ Carol Liu \\ W. P. Carey School of Business \\ Arizona State University \\ Gina Cavalier Rosa \\ College of Business Administration \\ University of New Orleans \\ Samuel L. Tiras* \\ Kelley School of Business \\ Indiana University-Indianapolis
}

June 2020

forthcoming The International Journal of Accounting (TIJA)

$\begin{aligned} \text { *Corresponding author. } & \text { Phone: (317) 274-3420; } \\ & \text { 801 W. Michigan Street, BS } 4004 \\ & \text { Indianapolis, IN 46202 } \\ & \text { email: stiras@iu.edu }\end{aligned}$

We thank Christine Cheng, Asher Curtis, Peter Demerjian, Dan Dhaliwal, Dave Farber, Danilo Monte-mor, Fernando Galdi, Betsy Gordon, Randy Heron, John Hassell, Greg Martin, Matt Wieland, and workshop participants at the 2016 Annual Congress of the European Accounting Association, 2016 ANPCONT Congress (Brazil), 2014 American Accounting Association annual meeting, Fucape Business School, Indiana University-Indianapolis, and University of Washington-Seattle for comments on previous versions of this study. Tiras wishes to thank IUPUI for funding this project through the International Research Development fund grant.

This is the author's manuscript of the article published in final edited form as: 


\title{
The Effects of Fair Value on the Matching of Revenues and Expenses: The Case of Asset Revaluations
}

\begin{abstract}
Researchers and practitioners have expressed concern that matching has declined over time, as evidenced by a decreasing association between revenues and expenses. They attribute this decline to the shift in financial reporting from a revenue-expense view that emphasizes matching, to an asset-liability view that emphasizes the measurement of economic resources that incorporates more fair values. When revenues rise with inflation but the expenses remain tied to historical costs, the two streams tend to diverge. We hypothesize that upwardly revaluing the long-lived fixed operating assets resets the expense stream; thus, changes in revenues will be more closely associated with changes in expenses for firms that revalue than firms that do not upwardly revalue. Based on a sample of United Kingdom firms, we find evidence supporting our expectations, particularly in those higher inflationary industries.
\end{abstract}

Keywords: asset revaluations; matching; fair value accounting; IFRS

Data Availability: Data are available from the sources listed in the text. 


\section{Introduction}

Dechow (1994) and Ball and Easton (2013) argue that the matching of revenues and expenses is an important principle guiding the calculation of earnings, as it helps mitigate timing issues inherent in cash flows. Gordon and Hsu (2018) point out, however, that a mismatch between cash outflows and cash inflows likely occurs when firms invest in long-lived fixed operating assets. If the cost of these fixed operating assets is not properly matched to the firm's revenues over time, the consequence is that profits would be misstated over the life of the asset. Graham, et al. (2005) argue that matching is important earnings attribute, as evidenced by Zimmerman and Bloom's (2016) finding that matching enhances the forecasting power of earnings.

Under International Financial Reporting Standards (IFRS), the prevailing view of financial reporting is that financial statements should be presented from an asset/liability viewpoint (IASB 2018a, para. 4.71; Gordon, et al., 2016). This view focuses foremost on measuring the economic resources of the firm and has resulted in an expanded use of fair values in financial reporting, as reflected in International Accounting Standard (IAS) No. 16 Property, Plant, and Equipment, among other standards. Dichev and Tang (2008) argue that this prevailing view and expanded use of fair values has led to a decline in the association between revenues and expenses over time (i.e., a decline in the matching). ${ }^{1}$

Because IFRS views performance as the change in a firm's economic resources over a reporting period, IFRS seemingly contradicts the normative view that a firm's performance results from the matching of efforts and accomplishments (i.e., the matching principle). This

Dichev and Tang's (2008) study is based on a sample of U.S. firms. But because the use of fair values is more prevalent under IFRS than U.S. GAAP, Dichev and Tang's (2008) assertion may be even more applicable for IFRS-adopting countries. For U.S. firms, Donelson et al. (2011) suggest that the decline in matching is attributable to the recognition of special items in earnings. 
viewpoint has led to a misconception that matching is not considered to be a desirable property of financial reporting under IFRS. The misconception arises because the International Accounting Standards Board (IASB) does not explicitly identify the matching principle as an objective of financial reporting in the current version of the Conceptual Framework for Financial Reporting (IASB, 2018a, para. 5.5) as well as its predecessor Conceptual Framework (IASB, 2010, para. 4.50). The IASB does argue, however, that matching arises from the recognition of changes in assets and liabilities. This is exemplified in IAS 2 Inventories, which effectively requires cost of goods sold be matched to revenues (IASB, 2003).

In the current study, we argue that upward asset revaluations for fixed operating assets resets the expense stream such that changes in revenues will be more closely associated with changes in expenses, thus improving matching. Upward asset revaluations recognize increases in the fixed operating asset's fair value gains, but the gains are recorded directly in equity through other comprehensive income (OCI). These gains are holding gains that result, in part, from inflation increasing the costs of the firm's operating assets (Konchitchki, 2011). While the revenue stream naturally increases with inflation, the expense stream is tied to lower historical values and rises only with revaluations. The resulting holding gains are never realized in earnings, but the higher asset values result in higher levels of depreciation that will be realized as an expense. Thus, upward asset revaluations are expected to mitigate the divergence of revenues from expenses as inflation rises. The purpose of our paper, therefore, is to test whether upward asset revaluations improve the matching of revenues and expenses.

The debate among standard setters, practitioners, and accounting researchers often centers on whether allowing more fair value measurements would improve the quality of financial reporting. For instance, while IFRS allows firms to upwardly revalue their operating 
assets, upward revaluations are strictly prohibited by the Financial Accounting Standards Board (FASB) in the United States. Botosan and Huffman (2015) argue that the appropriate asset measurement depends on the manner in which an asset is expected to realize value for the firm. For fixed operating assets, which realize value by being in use (as opposed to in exchange), they argue that financial reporting quality would be higher with the use of historical costs than with fair values.

The reasoning behind Botosan and Huffman's (2015) argument depends on accounting depreciation being a reasonable estimate of economic depreciation. But in light of inflation, any accounting depreciation method would fail to reasonably estimate economic depreciation. Upward revaluations formally recognize the current fair value of the asset in book value, where the subsequent depreciation of the updated book value corrects for historical cost's failure to match the current cost of the asset with the revenues.

Managers are typically reluctant to upwardly revalue their fixed operating assets because of the downward pressure on earnings that results from the additional depreciation. Christensen and Nikolaev (2013) claim that even where revaluation is allowed, CEOs are reluctant to upwardly revalue. Alternatively, Costa et al. (2020) point out that the choice to upwardly revalue serves as a signal of a firm's strong future prospects, and thus serves to reduce information asymmetry. The current study contributes to this debate by providing evidence that upward asset revaluations improve the quality of matching, thus increasing the quality of reported earnings.

We set our study in the United Kingdom for several reasons. ${ }^{2}$ First, we hope to draw the FASB's attention to the implications of upward revaluations on matching. As such, we favor

2 Our focus on the U.K. is in line with prior research on asset revaluations. For instance, Barth and Clinch (1996) examine the value relevance of asset revaluations in the U.K. and Aboody et al. (1999) test whether the revaluation reserve is predictive of future performance of U.K. firms. More recently, Costa et al. (2020) find that those firms 
restricting our study to a common law country, where our results would be more relevant to firms in the United States, rather than a broad cross section of countries. Secondly, we chose the U.K. in particular, because as of 2000 , the U.K. requires firms that voluntarily choose to upwardly revalue to continue to revalue their operating assets (at an interval no longer than five years). Finally, we restrict our study to just one country, because even with similar institutional environments, cross country differences persist that affect the usefulness of any particular accounting standard (Barth \& Clinch, 1996; Black, et al., 1998; Lourenço et al., 2018). ${ }^{3}$

Empirically, our first step is to perform a Propensity Score Matching procedure that matches firms that upwardly revalue their fixed operating assets to those that did not upwardly revalue, based on those firm characteristics Barlev et al. (2007), among others, identify as being associated with those firms that upwardly revalue. Next, we regress changes in revenues on changes in operating expenses to estimate their association and find evidence that the associations are stronger for revaluation firms than non-revaluation firms, particularly in highly inflationary industries. Our findings support our expectations that upwardly revaluing improves the matching of revenues and expenses by reversing the effects of inflation.

Our paper contributes to the policy debate over the use of fair value for operating assets by highlighting the effects in periods subsequent to revaluation. For standard setters in countries that do not currently allow upward asset revaluations, namely the U.S., our study suggests that

that upwardly revalue their fixed operating assets in the U.K. exhibit less information asymmetry than firms that do not upwardly revalue.

3 For example, even though accounting standards in the U.K. and Australia are very similar and apply upward revaluations in similar ways, Lourenço et al. (2018) show that U.K. and Australian firms belong to different clusters of countries in terms of accounting practices after IFRS adoption. As an additional test, we also tested whether upward asset revaluations improved the matching of revenues and expenses in Australia, but found no evidence supporting that premise, indicative of the differences noted by Lourenço et al. (2018). 
permitting firms to upwardly revalue their fixed operating assets may enhance financial statement quality.

Our study should be of interest to accounting researchers, practitioners, and financial statement users. Our study brings attention to the issue of matching, a topic that has been largely ignored despite its importance in the determination and quality of reported earnings (Dichev et al., 2013). The few studies that have examined the issue have concentrated primarily on the notion that the expanding use of fair values results in an increase in the proportion of expenses being recognized through impairments (Dichev \& Tang, 2008; Donelson et al., 2011; Prakash \& Sinha, 2012; Srivastava, 2014).

The remainder of the paper is organized as follows. Section 2 discusses the background literature and hypotheses development. Section 3 describes the sample selection and descriptive statistics. We present our results in Section 4 and conclude in Section 5.

\section{Background and Hypotheses Development}

\subsection{Standard Setters' Views on Matching}

Revenues are matched to expenses either directly, indirectly, or not at all. ${ }^{4}$ The most direct form of matching is when costs are directly matched with specific revenues, resulting in both the revenue and expense being recognized in income. An example of a cost that is directly matched is the recognition of cost of goods sold when a sale is recognized (IASB, 2010, para. 4.50; IASB 2018a, para. 5.5). Next, when the economic benefits of a particular cost are expected

4 IASB guidance points out that the process of recognizing revenue with directly related costs is "sometimes referred to as the matching of costs with income" (IASB, 2018a, para. 5.5). U.S. guidance further states that matching ranges from direct matching, to indirect matching, to nonmatching. This range is based on "three pervasive expense recognition principles," originally found in Accounting Principles Board (APB) Statement No 4 Basic Concepts and Accounting Principles Underlying Financial Statements of Business Enterprises (APB, 1970, pp. 154-161;) and reiterated in Statement of Financial Accounting Concept No. 6 Elements of Financial Statements (FASB, 1985, pp. 146-149). 
to rise over several accounting periods, the match between that cost and revenues can only be indirectly determined. In this case, expenses are recognized as a systematic allocation of costs (IASB, 2010, para. 4.51). This type of indirect matching occurs with the depreciation of assets, such as property, plant, and equipment (PP\&E). Finally, when costs that have been incurred are deemed to lack any future economic benefits, an expense is recognized immediately. ${ }^{5}$ In this case, expense recognition results without matching (IASB, 2010, para. 4.52). Asset impairments is an example of non-matching.

The IASB recognizes a concern of some respondents that the asset/liability viewpoint insufficiently acknowledges the importance of matching income and expenses within the Basis for Conclusions of the Conceptual Framework for Financial Reporting, (IASB 2018b, para. BC4.93). To this concern, the IASB maintains the long-held belief that it is more effective, efficient, and rigorous to define assets and liabilities first and then define performance as changes in assets and liabilities (IASB, 2018b, para. BC4.94(c)). The board emphasizes, however, that it is incorrect to assume that the statement of financial position is the primary focus of financial reporting. Rather, it emphasizes that financial statements are intended to provide information about both, an entity's financial position and its financial performance (IASB, 2018b, para. BC4.94(a)).

\subsection{Implications from the Accounting for Upward Asset Revaluations}

When inflation persists over an extended period of time, even if mild, the revenue and expense streams tend to diverge. This is because revenues rise with inflation and outpace the depreciation expense stream for assets that remain tied to lower, historical values. Consider the

5 By definition, impairments shift costs that would otherwise be matched to future revenues to being recognized as an expense of the current period. As such, the increasing use of impairments result in a smaller proportion of total costs recognized as direct or indirect matching, and a larger portion is recognized in the nonmatching category. 
example provided by Costa et al. (2020) where a firm recognizes an annual depreciation expense of $\$ 100$ based on an asset that originally cost $\$ 1,000$ with a useful life of 10 years (ignoring the tax effect). Assuming the firm revalues the asset and estimates the value to be $\$ 1,500$, the depreciation expense going forward would be $\$ 150$ per year. The increase of $\$ 50$ over the $\$ 100$ annual expense based on historical cost illustrates how the expense is reset to better match the rising revenue stream over the asset's remaining life.

By upward revaluations resetting the expense stream to reflect higher market prices, reported earnings would reflect firm performance free of any holding gains that result from inflation. If holding gains were not eliminated, operating expenses would be underreported to the extent of the holding gains, resulting in overstated reported profits. As far back as Edwards and Bell (1961), accounting researchers have acknowledged that a holding gain is not representative of firm performance. In an Edwards and Bell framework, upward revaluations bring the operating assets in line with current fair values, thus holding gains are recorded as a direct adjustment to equity rather than being realized in earnings. These holding gains are never recycled under IFRS, thus resulting in future earnings being reflective of only current performance.

While it may be intuitive that upward revaluations would mitigate the divergence of expenses from revenues, revaluations would be effective only if fair values can be reliably estimated, and these estimates are tied to the underlying level of inflation that affects a firm's revenues. Kolev (2009) and Song et al. (2010), among others, point out this concern by arguing that the lack of reliability detracts from the usefulness of fair value information. If the estimated market values of the operating assets are unreliable, or subject to the volatility and spikes in prices for a specific asset, the estimation of the inflationary effects on operating assets would not 
be reflective of the effects on nominal revenues. In this case, upwardly revaluing would simply inject noise into the cost of goods sold or depreciation expense.

\subsection{Prior Findings on Matching and Asset Revaluations}

Dichev and Tang (2008) find that over the past 40 years in the U.S., the contemporaneous association between revenues and expenses has declined. Based on the idea that earnings is the single most important output of the accounting system (Graham et al., 2005), Dichev and Tang's concern is that a breakdown in the matching of revenues and expenses has a detrimental impact on the determination of earnings. ${ }^{6}$ They warn that the FASB's continued shift away from matching and toward a more fair-valued accounting regime is likely to amplify this trend.

Others offer alternative explanations for the documented decline in matching in recent decades. For example, Donelson et al. (2011) conclude that the decline in matching is due mainly to an increase in special items that reflect economic developments. Prakash and Sinha (2012) point to deferred revenue as yet another source of concern for the quality of earnings. They find that changes in the current deferred revenue liability lead to reductions in earnings informativeness, which they partially attribute to the mismatch between deferred revenues and the associated product costs.

Finally, Srivastava (2014) finds that the matching of revenue and expenses is weaker for intangible intensive firms because the internally generated intangibles are generally expensed as incurred. Srivistava asserts that with the growth in intangible oriented firms, the extant literature's finding of a decline in matching may be attributable to a shift in sample composition.

$6 \quad$ Because upward asset revaluations are not permitted in the U.S., Dichev and Tang's (2008) concern applies only to asset impairments. Their arguments, however, clearly reflect their strong opposition to any move toward greater use of fair values. 
Together, the prior literature has provided evidence on the forces that drive the decline in matching over time, as well as the immediate effects on earnings quality. A limitation of these studies has been that they did not address how recognizing fair values on the balance sheet may affect the quality of future reported earnings. In particular, the extant literature has not examined how upwardly adjusting asset values (affecting financial condition) articulates with matching in future periods (affecting financial performance).

\subsection{Formal Hypothesis}

If revaluing resets the expense stream to better align the rising costs of a firm's fixed operating assets with the rising revenues, we would expect to observe changes in revenues will be more closely associated with changes in expenses for firms that upwardly revalue their fixed operating assets than firms that do not upwardly revalue. We express this formally in our hypothesis, as follows:

H1: For firms that upwardly revalue their fixed operating assets, changes in revenues will be more closely associated with changes in expenses, relative to firms that do not upwardly revalue.

\section{Empirical Development}

\subsection{Empirical Model}

To test our hypothesis that the association between revenues and expenses is stronger for firms that upwardly revalue their fixed operating assets, we use a two-stage approach. First, we apply a logistic regression in order to estimate the probability that a firm upwardly revalues. Because our goal is to test the effects from the choice of revaluation, rather than the underlying factors leading to the choice, we utilize a Propensity Score Matching (PSM) procedure, without replacement, in our empirical tests. In the second stage, we compare firms that revalue to firms 
that do not revalue, using the matched-pair design to evaluate the effects of revaluation on the matching of revenues and expenses.

In the first stage, the logistic regression considers factors the extant literature has identified as influential to explain the choice of a firm to upwardly revalue. Our approach mirrors the PSM approach found in Costa et al. (2020) in their analysis of the effectiveness of upward revaluations in reducing information asymmetry. We estimate Equation (1), presented below:

$$
\begin{aligned}
& \operatorname{Pr}\left(R_{i, t}=1\right)=\alpha_{0}+\alpha_{1} \text { Lev }_{i, t}+\alpha_{2} \text { Liq }_{i, t}+\alpha_{3} \text { Intense }_{i, t}+\alpha_{4} \text { BM }_{i, t} \\
& \quad+\alpha_{5} \text { ROA }_{i, t}+\alpha_{6} \text { Size }_{i, t}+\alpha_{7} \text { IFRS }_{i, t}+\alpha_{8} \text { Ind }+\alpha_{9} \text { Year }+\varepsilon_{i, t}
\end{aligned}
$$

where:

$$
\begin{aligned}
& R_{i, t}=\text { An indicator variable equal to } 1 \text { if firm } i \text { revalues its assets at time } t \text {; zero } \\
& L e v_{i, t}=\text { leverage for firm } i \text {, measured as the ratio of total debt to total assets } \\
& \mathrm{Liq}_{i, t}=\text { liquidity for firm } i \text {, measured as the ratio of current to total assets (exclusive } \\
& \text { of the effects of revaluation), at time } t \text {; } \\
& \text { Intense }_{i, t}=\text { capital intensity for firm } i \text {, measured as the ratio of net PP\&E to total assets } \\
& \text { (exclusive of the effects of revaluation), at time } t \text {; } \\
& B M_{i, t}=\text { the ratio of the book value (exclusive of the effects of revaluation) to the } \\
& \text { market value of equity for firm } i \text {, at time } t \text {; } \\
& R O A_{i, t}=\text { the ratio of net income before discontinued operations to total assets } \\
& \text { (exclusive of the effects of revaluation) for firm } i \text {, at time } t \text {; } \\
& \text { Size }_{i, t}=\text { the } \log \text { of total assets (exclusive of the effects of revaluation) for firm } i \text {, at } \\
& \text { time } t \text {; } \\
& \operatorname{IFRS} S_{i, t}=\text { an indicator variable equal to } 1 \text { if firm } i \text { reports under IFRS at time } t \text {; zero } \\
& \text { otherwise; } \\
& \text { Ind = industry fixed effects, based on the Fama-French 12-industry } \\
& \text { classification; and, } \\
& \text { Year }=\text { year fixed effects. }
\end{aligned}
$$

7 In calculating our variables, we remove the effects of the revaluation reserve from net assets to mitigate the possibility of a mechanical relation between the revaluation reserve and the correlation of revenues and expenses. 
Barlev et al. (2007) identify several factors that would likely influence the decision to revalue operating assets. In the context of our study, these factors would represent firm characteristics that would systematically differ across revaluation and non-revaluation firms. Our estimate of the propensity score is based on these factors.

Whittred and Chan (1992) find that firms with higher leverage are more likely to upwardly revalue their assets. Additionally, firms facing liquidity constraints may also revalue their assets to free up borrowing capacity (Barlev et al., 2007). As such, we include the ratio of total debt to total assets as our measure of firm leverage and the ratio of current to total assets as our measure of firm liquidity. Barlev et al. (2007) suggests that the level of assets that a firm has available for revaluation could be influential in either direction. As fixed operating assets may be used as collateral to facilitate borrowing, a low proportion of fixed operating assets would prompt managers to revalue and thus reveal current values of their assets. Alternatively, having a larger proportion of fixed operating assets would increase the impact of revaluation. Following Barlev et al. (2007) we include the ratio of net PP\&E to total assets, to capture a firm's capital intensity.

The extant literature offers arguments for both a positive and negative association between a firm's book to market ratio and asset revaluations (Lin \& Peasnell, 2000). On the one hand, a high book to market ratio may be positively associated with asset revaluations. On the other hand, a low ratio suggests that the market fails to correctly value a firm's assets, giving management incentives to revalue assets (Whittred \& Chan, 1992).

A firm's profitability and size have also been linked to asset revaluations. Barlev et al. (2007) suggest several reasons that firms with high return on assets would likely revalue fixed assets. These include concerns related to political costs and labor negotiations, as well as the 
ability to afford the downward pressure on earnings from higher depreciation levels. We include the ratio of net income before discontinued operations to total assets as a measure of firm profitability. Watts and Zimmerman (1986) suggest size is positively associated with asset revaluations due to political costs. Following Barlev et al. (2007), we include size as a control, based on the log of total assets (exclusive of the revaluation effects). We also include industry and year fixed effects.

From the first stage procedure, we identify matched pairs of revaluation and nonrevaluation firms. To evaluate if matching of revenues and expenses is higher for revaluation firms, we begin by adapting Dichev and Tang's (2008) model that regresses current revenues on current, lagged, and forward operating expenses. While their model regresses the level of revenues on the level of expenses to document the decline in matching over time (through the declining level of association over their sample period), our study focuses on how rising inflation influences the association between rising revenues and rising expenses. As such, we utilize a changes format of Dichev and Tang's (2008) model.

During our sample period, firms in the U.K. that upwardly revalue their fixed operating assets must consistently apply the revaluation standard, with a requirement that the firm revalues within five years. We consider this five-year period following a revaluation as a "revaluation window." In order to avoid regressing changes in current, lagged, and forward expenses in different revaluation windows, we do not consider year $t+1$, because changes in lagged expenses would be based in the previous revaluation window. Accordingly, we do not consider year $t+5$, because changes in forward expenses would be based in the following revaluation window (year $t+6)$. Therefore, in order to correctly capture the potential effects of revaluation in the expense stream in its subsequent years, we restrict our tests for each matched pair considering up to 3 
years of data, as follows: for a revaluation in year $t$, we set as current year $t+2$ (considering year $t+1$ as lagged and year $t+3$ as forward), year $t+3$ (considering year $t+2$ as lagged and year $t+4$ as forward), and year $t+4$ (considering year $t+3$ as lagged and year $t+5$ as forward).

We perform our second-stage tests by introducing a dummy $(0,1)$ indicator variable $R_{i, t}$ for revaluation firms. We interact $R_{i, t}$ with each of our regressors as well as including $R_{i, t}$ without interaction to allow for the intercept to vary across our matched pairs. Based on Cram et al. (2009), we also include matched-pair fixed effects, similar to the second stage analysis in Costa et al. (2020). Further, because our sample comprises both the pre- and post-IFRS adoption periods, we introduce a dummy $\left(\operatorname{IFRS} S_{i, t}\right)$ indicator variable in the model that is set to one for observations in the post-IFRS adoption period. The resulting test model, is as follows:

$$
\begin{gathered}
\Delta \operatorname{Rev}_{i, t}=\beta_{0}+\beta_{1} \operatorname{PairID}_{j, t}+\beta_{2} \Delta O p E x_{i, t}+\beta_{3} \Delta O p E x_{i, t-1}+\beta_{4} \Delta O p E x_{i, t+1}+\beta_{5} R_{i, t} \\
+\beta_{6} R . \Delta O p E x_{i, t}+\beta_{7} R . \Delta O p E x_{i, t-1}+\beta_{8} R . \Delta O p E x_{i, t+1}+\beta_{9} I F R S_{i, t}+\beta_{10} R . I F R S_{i, t+1}+\eta_{i, t}
\end{gathered}
$$

where:

$\Delta \operatorname{Rev}_{i, t}=$ changes in revenues for firm $i$, from time $t-1$ to time $t$;

PairID $_{i, t}=$ a fixed effect for each unique pair $j$ of revaluation and non-revaluation firms matched in the first stage (based on Equation 1); and,

$\triangle O p E x_{i, t}=$ operating expenses for firm $i$, from time $t-1$ to time $t$.

The remaining variables are as defined above. By controlling for those factors that are known to be associated with the choice to revalue in the first stage, the coefficient on $R . \Delta O p E x_{i, t}$ represents the difference in the association of changes in revenues and changes in expenses across our matched pairs of revaluation and non-revaluation firms. Support for our hypothesis will be reflected by a positive coefficient on $R . \Delta O p E x_{i, t}\left(\beta_{6}>0\right)$.

It is likely that the most direct effects from revaluation on the matching of revenues and expenses would be through depreciation expense. Therefore, we test this expectation by adapting the decomposition model developed by Donelson et al. (2011) by decomposing changes in 
operating expenses into changes in operating expenses (exclusive of depreciation) and changes in depreciation expense. The resulting test model is as follows:

$$
\begin{aligned}
& \Delta \operatorname{Rev}_{i, t}=\gamma_{0}+\gamma_{1} \text { PairID }_{j, t}+\gamma_{2} \Delta \text { Depr }_{i, t}+\gamma_{3} \Delta \text { OtherEx } x_{i, t}+\gamma_{4} \Delta O p E x_{i, t-1} \\
& +\gamma_{5} \Delta O p E x_{i, t+1}+\gamma_{6} R_{i, t}+\gamma_{7} R . \Delta \text { Depr }_{i, t}+\gamma_{8} R . \Delta O \text { therEx } x_{i, t}+\gamma_{9} R . \Delta O p E x_{i, t-1} \\
& +\gamma_{10} R . \Delta O p E x_{i, t+1}+\gamma_{11} \operatorname{IFRS}_{i, t}+\gamma_{12} \text { R.IFRS }_{i, t+1}+\kappa_{i, t}
\end{aligned}
$$

where:

$$
\begin{aligned}
\Delta \text { epr }_{i, t}= & \text { changes in depreciation expense for firm } i, \text { from time } t-1 \text { to time } t ; \text { and, } \\
\Delta \text { therEx }_{i, t}= & \text { operating expenses, exclusive of depreciation expense, for firm } i, \text { from } \\
& \text { time } t-1 \text { to time } t .
\end{aligned}
$$

The remaining variables are as defined above. Support for our main argument will be reflected

by a positive coefficient on $R . \Delta \operatorname{Depr}_{i, t}\left(\gamma_{7}>0\right)$.

\subsection{Sample Selection and Descriptive Statistics}

We collect data from Worldscope for all listed firms in the U.K. from 2000 to 2017. We begin our sample in 2000 in order to align our data with the effective dates for the U.K.'s requirement for firms that revalue to consistently apply the revaluation standard. Because we require data for a minimum of three years after a revaluation for each revaluation year, we consider revaluations only through 2014 . We identify those firms that revalue when there is a positive change in the revaluation reserve account, measured from period $t-1$ to $t .{ }^{8}$ To match a revaluation firm to a non-revaluation firm, we identify a non-revaluation firm if it has not

8 Our procedure mirrors that of Barlev et al. (2007) and Costa et al. (2020), in which they use Worldscope data and identify firms with positive changes in the Revaluation Reserve account as firms that revalue, because Worldscope does not disclose the amount revalued in a particular year. Both studies point out, however, that using the changes in the revaluation reserve as an identifier could lead to a bias in the sample selection process that could work against finding significant differences between revaluation and non-revaluation firms. Furthermore, our sample selection procedures would not identify those firms that reverse previous write-downs, for example, when a firm reverses a previous entry that leads to a timely loss recognition (TLR). We believe future research on the implications of reversing an entry designed as TLR would be compelling, but separate and distinct from the topic we are investigating in this study. 
revalued over the preceding five-year period, as required for firms choosing to revalue. We report our sample selection procedures in Table 1.

\section{$<$ Insert Table 1 $>$}

We identify 42,641 firm-year observations with available data on assets and revenues. We delete 607 firm-year observations with investment property, because prior to IAS 40 Investment Property became effective, revaluation of investment property was permitted to be recorded in the revaluation account. Thus, deleting firms with investment property mitigates misclassification errors. We also delete 11,976 firm-years in the financial industry and 568 firmyears in the utilities industries. We further delete 23,164 for missing data and 427 firm-years where the values for the variables fall outside normal convention (e.g., negative values for assets). The final sample consists of 5,899 firm-year observations, with revaluations occurring in $4.8 \%$ (286) of firm-year observations. Finally, we winsorize all variables by year at the 0.01 and 0.99 percentiles.

We present results for the logistic regression in Table 2. We find four of the six factors are significant, with a Pseudo $R^{2}$ of 0.2353 . Specifically, the coefficients are positive for $L e v_{i, t}$, $L_{i q} q_{i, t}$ Intense $_{i, t}$ and Size $_{i, t}$ (all significant at the one-percent level), but the coefficients on $B M_{i, t}$ and $R O A_{i, t}$ are not significant. We also find a negative coefficient for $I F R S_{i, t}$ (significant at the five-percent level).

\section{$<$ Insert Table 2>}

The results from our logistic regressions corroborate the findings of the prior literature in that we find significant associations between $R_{i, t}$ and those characteristics predicted to be determinants for why a firm may upwardly revalue. From the results of the logistic regressions, we calculate the propensity score for each observation. We form the matched sample by 
identifying the non-revaluation firm with the closest propensity score to each revaluation firm for a given revaluation year and industry (based on Fama and French 12-industry classifications), within a caliper of 0.2 (Imbens \& Rubin 2015) to increase the quality of the match between a revaluation firm and non-revaluation firm. This procedure results in 229 matched pairs. To evaluate the quality of the PSM procedure in matching revaluation to non-revaluation firms, we perform a covariate balance test, which we present in Table 3 .

\section{$<$ Insert Table 3>}

To the extent we find any significant differences in any of the determinants across the revaluation and non-revaluation firms, we would include those variables as controls in our second-stage tests. We find, however, no significant differences across our first-stage determinants, suggesting that the PSM procedure was effective in matching revaluation firms to non-revaluation firms. Further, because we collect up to three years of data in order to regress changes in revenues on changes in expenses, the maximum number of matched-pair firm-years is (229 x 3) 687. Because some firms revalue in a window less than five years, our final sample consists of 253 matched-pair firm-years or 506 firm-year observations.

We present the industry distributions of the matched pairs in Table 4 . The most represented industries are Other (36.8\%), Shops (16.2\%), and Business Equipment (15.4\%). The overrepresentation of the "Other" category likely weakens our matching procedure, but the small sample size restricts our use of the Fama and French 30 or 48 industry classifications.

\section{$<$ Insert Table 4>}

\section{Empirical Results}

In Panel A of Table 5, we present our results from testing equation (2) that regresses changes in revenues on changes in operating expenses. We report four model specifications of 
equation (2). Model 1 serves as our baseline regression by excluding the indicator variable $R_{i, t}$. In this specification, we also omit changes in operating expenses from $t-1$ and $t+1$. Model 2 also serves as a baseline regression, but includes changes in operating expenses from $t-1$ and $t+1$ to control for the timing effects of expenses. Model 3 serves as our test model that modifies Model 1 by including $R_{i, t}$ as a regressor and the interactions $R_{i, t}$ with changes in operating expenses. Finally, Model 4 serves as our full test model by modifying Model 2 by including $R_{i, t}$ as a regressor and the interactions of $R_{i, t}$ with changes in operating expenses from $t-1$ and $t+1$.

\section{<Insert Table 5>}

We find in the baseline regressions from Models 1 and 2 that the coefficients on $\triangle O p E x_{i, t}$ are positive (coefficients of 0.968 and 0.957 respectively, both significant at the one-percent level), indicative of the strong matching between changes in revenues and changes in expenses.

When we include the interactions of $\triangle O p E x_{i, t}$ with $R_{i, t}$ in Models 3 and 4, the coefficients $\triangle O p E x_{i, t}$ represent the matching of revenues and expenses for sample non-revaluation firms and $R . \triangle O p E x_{i, t}$ represents the extent that matching differs for our sample revaluation firms. We find that the coefficients on $\triangle O p E x_{i, t}$ are still strongly significant (coefficients of 0.936 and 0.922 respectively for Models 3 and 4, both significant at the one-percent level), but lower than we found when testing Models 1 and 2. Further, we find that on our variable of interest $R . \Delta O p E x_{i, t}$ for testing Models 3 and 4 (coefficients of 0.099 and 0.103 respectively, both significant at the five-percent level). The smaller coefficients on $\triangle O p E x_{i, t}$ and significantly positive coefficients on $R . \Delta O p E x_{i, t}$ provides evidence that suggests matching is stronger for revaluation firms than for non-revaluation firms and lends support for our hypothesis.

In Panel B of Table 5, we present the results from the disaggregated model found in equation (3). Models 1 and 2 again serve as our baseline models and Models 3 and 4 serve as 
our test models. Focusing on the coefficients on $\Delta D e p r_{i, t}$ on $R . \Delta D e p r_{i, t}$, we do not find $\Delta D e p r_{i, t}$ to be significant across any of the four model specifications, indicative that change in revenues are not associated with changes in depreciation for the non-revaluation firms. We do find, however, that the coefficients on R. $\Delta D e p r_{i, t}$ are positive and significant (coefficients of 1.396 and 1.025 respectively, both significant at the one- and five-percent level) for Models 3 and 4. Because the resetting of the expense stream from upward asset revaluations is tied to increasing the stream of depreciation, these additional findings suggest that the differences we document are tied to the choice to upwardly revalue and further supports our hypothesis.

We perform one additional set of tests designed to specifically address whether inflation is driving the results we observe above, which is the underlying premise of our hypothesis. If the underlying inflation is driving our results, we would expect to observe the effects of upward asset revaluation to be stronger on the matching of revenues and expenses in industries more prone to inflation. We therefore partition our sample on whether the specific inflation index for an industry falls above (high) or below (low) our sample median..$^{9}$ Focusing on the decomposed model from equations (3), with the expectation that our results will be most pronounced in the high inflationary subsample, we present our results in Table 6.

\section{$<$ Insert Table 6>}

We find for the high-inflationary subsample presented in Panel A, we find that the coefficients on $R . \Delta D e p r_{i, t}$ in Models 3 and 4 are again positive and significant (coefficients of 2.362 and 1.730, respectively, both significant at the one-percent level). For the low-inflationary sample presented in Panel B, we do not find $R . \Delta D e p r_{i, t}$ differs from zero. Together, the findings

\footnotetext{
${ }^{9}$ We classify the following industries as "high inflation": nondurables, durables, energy, chemicals, shops, healthcare and other. We classify the following industries as "low inflation": manufacturing, business equipment, and telcom.
} 
from these additional tests provide more direct evidence that suggests that upward asset revaluations improve the matching of revenues and expenses by resetting the depreciation expense stream to reflect rising inflation.

\section{Conclusion}

Studies that examine the changes in earnings attributes over time document a decline in matching of revenue and expenses. Dichev and Tang (2008), one of the first studies to examine changes in matching, attribute this decline to standard setters moving away from the revenueexpense view that emphasizes matching to an asset/liability view that emphasizes measuring economic resources. This shift reflects the misconception that the matching concept is at odds with the application of fair values within the asset-liability view.

In the current study, we argue and provide evidence using data from the U.K. that the use

of fair values for upwardly revaluating fixed operating assets resets the expense stream to reflect rising inflation, such that changes in revenues will be more closely associated with changes in expenses for firms that revalue than firms that do not upwardly revalue. In additional tests, we find that the resetting is specifically related to depreciation expense and affects the matching of revenues and expenses in those industries with high inflation.

Our findings that upward asset revaluation improve the matching of revenues and expenses suggest that upward asset revaluations improve the quality of reported earnings and contribute to the understanding of the relation between fair values and matching. Our findings can also serve as guidance to the U.S. and other jurisdictions as they continue to contemplate whether to allow firms to upwardly revalue operating assets. 


\section{References}

Aboody, D., Barth, M. E., \& Kasznik, R. (1999). Revaluations of fixed assets and future firm performance: Evidence from the UK. Journal of Accounting \& Economics, 26(1-3), 149178.

Accounting Principles Board (APB). (1970). Statement No. 4 Basic Concepts and Accounting Principles Underlying Financial Statements of Business Enterprises.

Ball, R. T., \& Easton, P. (2013). Dissecting earnings recognition timeliness. Journal of Accounting Research, 51(5), 1099-1132.

Barlev, B., Fried, D., Haddad, J. R., \& Livnat, J. (2007). Reevaluation of revaluations: A crosscountry examination of the motives and effects on future performance. Journal of Business Finance \& Accounting, 34(7-8), 1025-1050.

Barth, M. E., \& Clinch, G. (1996). International accounting differences and their relation to share prices: Evidence from U.K., Australian, and Canadian firms. Contemporary Accounting Research, 13(1), 135-170.

Black, E. L., Sellers, K. F., \& Manly, T. S. (1998). Earnings management using asset sales: An international study of countries allowing noncurrent asset revaluation. Journal of Business Finance \& Accounting, 25(9-10), 1287-1317.

Botosan, C., \& Huffman, A. (2015). Decision-useful asset measurement from a business valuation perspective. Accounting Horizons, 29(4), 757-776.

Christensen, H., \& Nikolaev, V. (2013). Does fair value accounting for non-financial assets pass the market test? Review of Accounting Studies, 18(3), 734-775.

Costa, F., Liu, C., Rosa, G., \& Tiras, S. (2020). The commitment to income-decreasing accounting choices as a credible signal to reduce information asymmetry: The case of asset revaluations. Contemporary Accounting Research, in press.

Cram, D. P., Karan, V., \& Stuart, I. (2009). Three threats to validity of choice-based and matched-sample studies in accounting research. Contemporary Accounting Research, 26(2), 477-516.

Dechow, P. (1994). Accounting earnings and cash flows as measures of firm performance: The role of accounting accruals. Journal of Accounting \& Economics, 18(1), 3-42.

Dichev, I. D., Graham, J., Harvey, C. R., \& Rajgopal, S. (2013). Earnings quality: Evidence from the field. Journal of Accounting \& Economics, 56(2-3), 1-33.

Dichev, I. D., \& Tang, W. (2008). Matching and the changing properties of accounting earnings over the last 40 years. The Accounting Review, 83(6), 1425-1460. 
Donelson, D., Jennings, R., \& McInnis, J. (2011). Changes over time in the revenue-expense relation: Accounting or economics? The Accounting Review, 86(3), 945-974.

Edwards, E. O., \& Bell, P. W. (1961). The theory of and measurement of business income. University of California Press.

Gordon, E. A., \& Hsu, J. T. (2018). Tangible long-lived asset impairments and future operating cash flows under U.S. GAAP and IFRS. The Accounting Review, 93(1), 187-211.

Gordon, E. A., Ready, J. S., \& Sannella, A. J. (2016). Intermediate accounting. Pearson Education Inc.

Graham, J., Harvey, C. R., \& Rajgopal, S. (2005). The economic implications of corporate financial reporting. Journal of Accounting \& Economics, 40(1-3): 3-73.

Imbens, G., \& Rubin, D. (2015). Causal inference for statistics, social, and biomedical sciences: An introduction. Cambridge University Press.

International Accounting Standards Board (IASB). (2003). International Accounting Standard No. 2 Inventories. IASB.

International Accounting Standards Board (IASB). (2003). International Accounting Standard No. 16 Property, plant, and equipment. IASB. https://www.iasplus.com/en/standards/ias/ias16

International Accounting Standards Board (IASB). (2003). International Accounting Standard No. 40 Investment property. IASB. https://www.iasplus.com/en/standards/ias/ias40

International Accounting Standards Board (IASB). (2010). Conceptual framework for financial reporting. IASB. https://www.ifrs.org/issued-standards/list-of-standards/conceptualframework/

International Accounting Standards Board (IASB). (2015). Basis for conclusions on the exposure draft conceptual framework for financial reporting. IASB. http://archive.ifrs.org/CurrentProjects/IASB-Projects/Conceptual-Framework/Documents/May\%202015/Basis-toED_CF_MAY\%202015.pdf

International Accounting Standards Board (IASB). (2018a). Conceptual framework for financial reporting. IASB. https://www.ifrs.org/-/media/project/conceptual-framework/fact-sheetproject-summary-and-feedback-statement/conceptual-framework-project-summary.pdf

International Accounting Standards Board (IASB). (2018b). Basis for conclusions on the conceptual framework for financial reporting. IASB.

Kolev, K. (2009). Do investors perceive marking-to-model as marking-to-myth? Early evidence from FAS 157. Working paper, Yale University. 
Konchitchki, Y. (2011). Inflation and nominal financial reporting: Implications for performance and stock prices. The Accounting Review, 86(3), 1045-1085.

Lourenço, I. S., Sarquis, R., Branco, M. C., \& Magro, N. (2018). International differences in accounting practices under IFRS and the influence of the US. Australian Accounting Review, 87(4), 468-481.

Lin, Y. C., \& Peasnell, K. V. (2000). Fixed asset revaluation and equity depletion in the UK. Journal of Business Finance \& Accounting, 27(3-4), 359-394.

Prakash, R., \& Sinha, N. (2012). Deferred revenues and the matching of revenues and expenses. Contemporary Accounting Research, 20(2), 517-548.

Song, C., Thomas, W., \& Yi, H. (2010). Value relevance of FAS 157 fair value hierarchy information and the impact of corporate governance mechanisms. The Accounting Review, 85(4), 1375-1410.

Srivastava, A. (2014). Why have measures of earnings quality changed over time? Journal of Accounting \& Economics, 57(2-3), 196-217.

Watts, R. L., \& Zimmerman, J. L. (1986). Positive Accounting Theory. Prentice-Hall.

Whittred, G., \& Chan, Y. K. (1992). Asset revaluations and the mitigation of underinvestment. Abacus, 28(1): 3-35.

Zimmerman, A. B., \& Bloom, R. (2016). The matching principle revisited. Accounting Historians Journal, 43(1): 79-120. 
TABLE 1

Sample Selection and Screening Procedures

Initial firm-years available from

Worldscope database, 2000-2014

42,641

Less firm-years:

firms with investment property

607

financial institutions

11,976

utilities

568

missing data

23,164

values outside normal convention

427

Final sample

5,899

Revaluation Firm Years

286

$\%$ Revaluation Firms

$4.8 \%$ 
TABLE 2

Logit Regression: Propensity Score Matching

\begin{tabular}{|c|c|}
\hline Variable & Coefficients \\
\hline Intercept & $\begin{array}{r}\mathbf{- 1 3 . 6 3 7} \\
-10.42\end{array}$ *** \\
\hline$L e v_{i, t}$ & $\begin{array}{r}\mathbf{0 . 8 4 7} \\
2.45 \text { *** }\end{array}$ \\
\hline $\operatorname{Liq}_{i, t}$ & $\begin{array}{r}4.361 \\
9.50 * * *\end{array}$ \\
\hline Intense $_{i, t}$ & $\begin{array}{r}\mathbf{5 . 4 4 5} \\
15.23\end{array}$ *** \\
\hline$B M_{i, t}$ & $\begin{array}{r}\mathbf{0 . 0 9 6} \\
1.12\end{array}$ \\
\hline $\boldsymbol{R O} A_{i, t}$ & $\begin{array}{r}\mathbf{0 . 8 6 8} \\
1.63\end{array}$ \\
\hline$S_{i z} e_{i, t}$ & $\begin{array}{r}2.256 \\
4.98\end{array}$ \\
\hline $\operatorname{IFRS}_{i, t}$ & 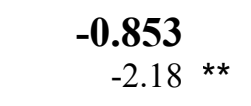 \\
\hline Industry Dummies included & yes \\
\hline Year Dummies included & yes \\
\hline$R 2$ & 0.2353 \\
\hline$N$ & 5,899 \\
\hline
\end{tabular}




\section{TABLE 2 (CONTINUED)}

\section{Notes:}

${ }^{*},{ }^{* *},{ }^{* * *}$ indicate significant at the 10,5 , and 1 percent levels, respectively.

Industry dummies based on Fama-French 12.

Variables are defined as follows:

$L E V_{i, t}=$ leverage for firm $i$, measured as the ratio of total debt to total assets (exclusive of the effects of revaluation), at time $t$;

$L I Q_{i, t}=$ liquidity for firm $i$, measured as the ratio of current to total assets (exclusive of the effects of revaluation), at time $t$

$I N T E N S E_{i, t}=$ capital intensity for firm $i$, measured as the ratio of net PP\&E to total assets (exclusive of the effects of revaluation), at time $t$;

$B M_{i, t}=$ the ratio of the book value (exclusive of the effects of revaluation) to the market value of equity for firm $i$, at time $t$;

$R O A_{i, t}=$ the ratio of net income before discontinued operations to total assets (exclusive of the effects of revaluation) for firm $i$, at time $t$;

$S I Z E_{i, t}=\log$ of total assets (exclusive of the effects of revaluation) for firm $i$ in year $t-1$; and,

$I F R S_{i, t}=$ an indicator variable equal to 1 if year $t$ is 2005 or after; 0 , otherwise. 
TABLE 3

Covariate Balance between Matched Pairs of First Stage Determinants

\begin{tabular}{|c|c|c|c|c|c|c|c|}
\hline \multirow[b]{2}{*}{ Variable } & \multicolumn{3}{|c|}{$\begin{array}{c}\text { Revaluation } \\
\text { Subsample }(n=229) \\
\end{array}$} & \multicolumn{3}{|c|}{$\begin{array}{c}\text { Non-Revaluation } \\
\text { Subsample }(n=229)\end{array}$} & \multirow[t]{2}{*}{$\begin{array}{c}\text { Differences } \\
\text { in Means } \\
\end{array}$} \\
\hline & Mean & Median & S.D. & Mean & Median & S.D. & \\
\hline$L E V i_{, t}$ & 0.557 & 0.553 & 0.205 & 0.562 & 0.581 & 0.215 & $(0.005)$ \\
\hline$L I Q i_{, t}$ & 0.512 & 0.544 & 0.265 & 0.487 & 0.486 & 0.291 & 0.024 \\
\hline INTENSE $i_{, t}$ & 0.414 & 0.355 & 0.311 & 0.423 & 0.356 & 0.319 & $(0.008)$ \\
\hline$B M i_{, t}$ & 0.813 & 0.672 & 0.649 & 0.794 & 0.604 & 0.688 & 0.019 \\
\hline$R O A i_{, t}$ & 0.029 & 0.042 & 0.111 & 0.028 & 0.048 & 0.117 & 0.001 \\
\hline$S I Z E_{i, t}$ & 2.461 & 2.475 & 0.172 & 2.456 & 2.434 & 0.174 & 0.005 \\
\hline
\end{tabular}

Notes:

${ }^{*},{ }^{* *},{ }^{* *}$ indicate significant at the 10,5 , and 1 percent levels, respectively.

See Table 2 for variable definitions. 
TABLE 4

Industry Distribution of Matched-Pair Sample

\begin{tabular}{|c|c|c|}
\hline Fama-French Industry & $\mathbf{N}$ & Percent \\
\hline Nondurables & 20 & $4.0 \%$ \\
\hline Durables & 16 & $3.2 \%$ \\
\hline Manufacturing & 60 & $11.9 \%$ \\
\hline Energy & 32 & $6.3 \%$ \\
\hline Chemicals & 4 & $0.8 \%$ \\
\hline Business Equipment & 78 & $15.4 \%$ \\
\hline Telcom & 14 & $2.8 \%$ \\
\hline Shops & 82 & $16.2 \%$ \\
\hline Healthcare & 14 & $2.8 \%$ \\
\hline Other & 186 & $36.8 \%$ \\
\hline Total & 506 & $100.0 \%$ \\
\hline
\end{tabular}

Notes:

Industry classifications based on Fama-French 12 . 
TABLE 5

Results from Regressing the Revenues on Operating Expenses across Revaluation and Non-Revaluation firms

Panel A: Aggregated Model

\begin{tabular}{|c|c|c|c|c|c|}
\hline Variable & E(Sign) & Model 1 & Model 2 & Model 3 & Model 4 \\
\hline Intercept & $?$ & $\begin{array}{r}\mathbf{0 . 0 1 5} \\
0.27\end{array}$ & $\begin{array}{r}\mathbf{0 . 0 1 8} \\
0.32\end{array}$ & $\begin{array}{r}\mathbf{0 . 0 2 1} \\
0.37\end{array}$ & $\begin{array}{r}\mathbf{0 . 0 2 2} \\
0.41\end{array}$ \\
\hline$\Delta O p E x_{i, t}$ & + & $\begin{array}{r}\mathbf{0 . 9 6 8} \\
49.87 * * *\end{array}$ & $\begin{array}{r}\mathbf{0 . 9 5 7} \\
51.40 \text { *** }\end{array}$ & $\begin{array}{r}\mathbf{0 . 9 3 6} \\
39.86 * * *\end{array}$ & $\begin{array}{c}0.922 \\
40.68 \text { *** }\end{array}$ \\
\hline$\Delta O p E x_{i, t-1}$ & $?$ & & $\begin{array}{r}-\mathbf{0 . 0 6 1} \\
-3.27 * * *\end{array}$ & & $\begin{array}{r}-\mathbf{0 . 0 2 2} \\
-0.83\end{array}$ \\
\hline$\Delta O p E x_{i, t+1}$ & $?$ & & $\begin{array}{r}-\mathbf{0 . 1 0 7} \\
-4.82 * * *\end{array}$ & & $\begin{array}{r}-\mathbf{0 . 1 4 1} \\
-4.95 * * *\end{array}$ \\
\hline $\boldsymbol{R}_{i, t}$ & $?$ & & & $\begin{array}{r}-\mathbf{0 . 0 1 0} \\
-0.75\end{array}$ & $\begin{array}{r}\mathbf{- 0 . 0 0 3} \\
-0.24\end{array}$ \\
\hline$R . \Delta O p E x_{i, t}$ & + & & & $\begin{array}{r}\mathbf{0 . 0 9 9} \\
2.33 \text { ** }\end{array}$ & $\begin{array}{r}\mathbf{0 . 1 0 3} \\
2.49 \text { ** }\end{array}$ \\
\hline$R . \Delta O p E x_{i, t-1}$ & $?$ & & & & $\begin{array}{r}-\mathbf{0 . 0 6 3} \\
-1.67 \text { * }\end{array}$ \\
\hline$R . \Delta O p E x_{i, t+1}$ & $?$ & & & & $\begin{array}{r}\mathbf{0 . 0 7 7} \\
1.81 \text { * }\end{array}$ \\
\hline $\operatorname{IFRS}_{i, t}$ & $?$ & $\begin{array}{r}\mathbf{0 . 0 1 6} \\
0.56\end{array}$ & $\begin{array}{r}\mathbf{0 . 0 3 2} \\
1.16\end{array}$ & $\begin{array}{r}\mathbf{0 . 0 1 1} \\
0.37\end{array}$ & $\begin{array}{r}\mathbf{0 . 0 3 4} \\
1.20\end{array}$ \\
\hline$R_{. I F R S_{i, t+1}}$ & $?$ & & & $\begin{array}{r}\mathbf{0 . 0 0 9} \\
0.56\end{array}$ & $\begin{array}{r}\mathbf{- 0 . 0 0 7} \\
-0.44\end{array}$ \\
\hline \multicolumn{2}{|c|}{ PAIRID dummies included } & yes & yes & yes & yes \\
\hline$R^{2}$ & & 0.884 & 0.894 & 0.885 & 0.898 \\
\hline$N$ & & 506 & 506 & 506 & 506 \\
\hline
\end{tabular}


TABLE 5 (CONTINUED)

Panel B: Disaggregated Model

\begin{tabular}{|c|c|c|c|c|c|}
\hline Variable & E(Sign) & Model 1 & Model 2 & Model 3 & Model 4 \\
\hline Intercept & $?$ & $\begin{array}{r}\mathbf{0 . 0 1 6} \\
0.29\end{array}$ & $\begin{array}{r}\mathbf{0 . 0 1 8} \\
0.34\end{array}$ & $\begin{array}{r}\mathbf{0 . 0 1 9} \\
0.34\end{array}$ & $\begin{array}{r}\mathbf{0 . 0 2 0} \\
0.38\end{array}$ \\
\hline$\Delta D e p r_{i, t}$ & + & $\begin{array}{r}\mathbf{0 . 1 9 4} \\
0.77\end{array}$ & $\begin{array}{r}\mathbf{0 . 2 4 4} \\
1.02\end{array}$ & $\begin{array}{r}-\mathbf{0 . 3 5 0} \\
-1.06\end{array}$ & $\begin{array}{r}-\mathbf{0 . 0 6 5} \\
-0.20\end{array}$ \\
\hline$\Delta O$ therEx $x_{i, t}$ & + & $\begin{array}{l}\mathbf{0 . 9 7 5} \\
49.94_{* * *}\end{array}$ & $\begin{array}{c}\mathbf{0 . 9 6 4} \\
51.34_{* * *}\end{array}$ & $\begin{array}{l}\mathbf{0 . 9 5 2} \\
40.20 * * *\end{array}$ & $\begin{array}{r}\mathbf{0 . 9 3 6} \\
40.10 \text { *** }\end{array}$ \\
\hline$\Delta O p E x_{i, t-1}$ & $?$ & & $\begin{array}{r}-\mathbf{0 . 0 6 5} \\
-3.52 \text { *** }\end{array}$ & & $\begin{array}{r}-\mathbf{0 . 0 3 3} \\
-1.24\end{array}$ \\
\hline$\Delta O p E x_{i, t+1}$ & $?$ & & $\begin{array}{r}\mathbf{- 0 . 1 0 0} \\
-4.47 * * *\end{array}$ & & $\begin{array}{r}-\mathbf{0 . 1 1 8} \\
-4.04\end{array}$ *** \\
\hline $\boldsymbol{R}_{i, t}$ & $?$ & & & $\begin{array}{r}-\mathbf{0 . 0 0 2} \\
-0.12\end{array}$ & $\begin{array}{r}\mathbf{0 . 0 0 1} \\
0.11\end{array}$ \\
\hline$R . \Delta D e p r_{i, t}$ & + & & & $\begin{array}{l}1.396 \\
2.73 * * *\end{array}$ & $\begin{array}{l}1.025 \\
2.07 \text { ** }\end{array}$ \\
\hline R.AOtherEx $x_{i, t}$ & + & & & $\begin{array}{l}\mathbf{0 . 0 8 5} \\
2.02 * *\end{array}$ & $\begin{array}{l}\mathbf{0 . 0 9 0} \\
2.16^{\text {** }}\end{array}$ \\
\hline$R . \Delta O p E x_{i, t-1}$ & $?$ & & & & $\begin{array}{r}-\mathbf{0 . 0 5 3} \\
-1.40\end{array}$ \\
\hline$R . \Delta O p E x_{i, t+1}$ & $?$ & & & & $\begin{array}{c}\mathbf{0 . 0 7 7} \\
1.81 \text { * }\end{array}$ \\
\hline $\operatorname{IFRS}_{i, t}$ & $?$ & $\begin{array}{r}\mathbf{0 . 0 1 0} \\
0.35\end{array}$ & $\begin{array}{r}\mathbf{0 . 0 2 5} \\
0.90\end{array}$ & $\begin{array}{r}\mathbf{0 . 0 0 7} \\
0.23\end{array}$ & $\begin{array}{r}\mathbf{0 . 0 2 7} \\
0.96\end{array}$ \\
\hline $\operatorname{R.IFRS}_{i, t+1}$ & $?$ & & & $\begin{array}{r}\mathbf{0 . 0 0 1} \\
0.07\end{array}$ & $\begin{array}{r}-\mathbf{0 . 0 1 0} \\
-0.66\end{array}$ \\
\hline \multicolumn{2}{|c|}{ PAIRID dummies included } & yes & yes & yes & yes \\
\hline$R^{2}$ & & 0.886 & 0.896 & 0.889 & 0.936 \\
\hline$N$ & & 506 & 506 & 506 & 506 \\
\hline
\end{tabular}




\section{TABLE 5: (CONTINUED)}

\section{Notes:}

${ }^{*},{ }^{* *},{ }^{* * *}$ indicate significant at the 10,5 , and 1 percent levels, respectively.

The dependent variable is $\Delta \operatorname{Rev}_{i, t}$.

Variable definitions are as follows:

$\Delta \operatorname{Rev}_{i, t}=$ change in revenues for firm $i$ at time $t$;

$\triangle O p E x_{i, t-j}=$ change in operating expenses for firm $i$ at time $t+j, j \epsilon[-1,0,1]$;

$\Delta$ Depr $_{i, t}=$ change in depreciation expense for firm $i$ at time $t$;

$\Delta O$ therEx $_{i, t}=$ change in operating expenses, exclusive of depreciation expense, for firm $i$ at time $t$;

$R_{i, t}=$ an indicator variable equal to 1 if firm i revalues its assets at time $\mathrm{t}$; zero otherwise;

PairID $_{i, t}=$ a fixed effect for each pair of revaluation and non-revaluation firm identified in the first stage (based on Equation 1); and,

$I F R S_{i, t}=$ an indicator variable equal to 1 if year $t$ is 2005 or after; 0 , otherwise. 
TABLE 6

Results from Regressing the Revenues on Operating Expenses across Revaluation and Non-Revaluation firms - partitioned by High and Low Inflation Industries

Panel A: High Inflation Industries

\begin{tabular}{|c|c|c|c|c|c|}
\hline Variable & E(Sign) & Model 1 & Model 2 & Model 3 & Model 4 \\
\hline Intercept & $?$ & $\begin{array}{r}\mathbf{0 . 0 1 7} \\
0.27\end{array}$ & $\begin{array}{r}\mathbf{0 . 0 2 0} \\
0.34\end{array}$ & $\begin{array}{r}\mathbf{0 . 0 2 0} \\
0.32\end{array}$ & $\begin{array}{r}\mathbf{0 . 0 2 1} \\
0.37\end{array}$ \\
\hline$\Delta D e p r_{i, t}$ & + & $\begin{array}{r}-\mathbf{0 . 0 8 6} \\
-0.26\end{array}$ & $\begin{array}{r}-\mathbf{0 . 0 1 3} \\
-0.04\end{array}$ & $\begin{array}{r}\mathbf{- 1 . 3 2 6} \\
-2.73\end{array}$ & $\begin{array}{r}-\mathbf{0 . 7 8 6} \\
-0.17\end{array}$ \\
\hline$\Delta O$ therEx $_{i, t}$ & + & $\begin{array}{r}\mathbf{0 . 9 6 6} \\
39.14\end{array}$ & $\begin{array}{r}\mathbf{0 . 9 5 5} \\
40.94 * * *\end{array}$ & $\begin{array}{r}\mathbf{0 . 9 6 4} \\
31.70 \text { *** }\end{array}$ & $\begin{array}{r}\mathbf{0 . 9 3 5} \\
31.62\end{array}$ \\
\hline$\Delta O p E x_{i, t-1}$ & $?$ & & $\begin{array}{r}-\mathbf{0 . 0 6 7} \\
-2.88 \text { *** }\end{array}$ & & $\begin{array}{r}-\mathbf{0 . 0 3 5} \\
-1.08\end{array}$ \\
\hline$\Delta O p E x_{i, t+1}$ & $?$ & & $\begin{array}{r}-\mathbf{0 . 1 2 7} \\
-4.64 * * *\end{array}$ & & $\begin{array}{r}-\mathbf{0 . 1 6 4} \\
-4.33 * * *\end{array}$ \\
\hline $\boldsymbol{R}_{i, t}$ & $?$ & & & $\begin{array}{r}-\mathbf{0 . 0 0 0} \\
-0.02\end{array}$ & $\begin{array}{r}\mathbf{0 . 0 0 6} \\
0.36\end{array}$ \\
\hline$R . \Delta D e p r_{i, t}$ & + & & & $\begin{array}{l}\mathbf{2 . 3 6 2} \\
3.60 * * *\end{array}$ & $\begin{array}{l}1.730 \\
2.75 \text { *** }\end{array}$ \\
\hline$R . \Delta O t h e r E x_{i, t}$ & + & & & $\begin{array}{r}\mathbf{0 . 0 5 1} \\
0.97\end{array}$ & $\begin{array}{r}\mathbf{0 . 0 8 2} \\
1.60\end{array}$ \\
\hline$R . \Delta O p E x_{i, t-1}$ & $?$ & & & & $\begin{array}{r}-\mathbf{0 . 0 4 6} \\
-1.00\end{array}$ \\
\hline$R . \Delta O p E x_{i, t+1}$ & $?$ & & & & $\begin{array}{r}\mathbf{0 . 0 8 9} \\
1.72 \text { * }\end{array}$ \\
\hline $\operatorname{IFRS}_{i, t}$ & $?$ & $\begin{array}{r}\mathbf{0 . 0 3 5} \\
0.87\end{array}$ & $\begin{array}{r}\mathbf{0 . 0 5 4} \\
1.43\end{array}$ & $\begin{array}{r}\mathbf{0 . 0 2 6} \\
0.64\end{array}$ & $\begin{array}{r}\mathbf{0 . 0 5 4} \\
1.39\end{array}$ \\
\hline$R_{I F R S_{i, t+1}}$ & $?$ & & & $\begin{array}{r}-\mathbf{0 . 0 0 1} \\
-0.04\end{array}$ & $\begin{array}{r}-\mathbf{0 . 0 1 8} \\
-0.94\end{array}$ \\
\hline \multicolumn{2}{|c|}{ PAIRID dummies included } & yes & yes & yes & yes \\
\hline$R^{2}$ & & 0.874 & 0.888 & 0.880 & 0.894 \\
\hline$N$ & & 352 & 352 & 352 & 352 \\
\hline
\end{tabular}


TABLE 6 (CONTINUED)

Panel B: Low Inflation Industries

\begin{tabular}{|c|c|c|c|c|c|}
\hline Variable & E(Sign) & Model 1 & Model 2 & Model 3 & Model 4 \\
\hline Intercept & ? & $\begin{array}{r}-\mathbf{0 . 1 2 1} \\
-2.63\end{array}$ & $\begin{array}{c}-\mathbf{0 . 1 1 5} \\
-2.50 \text { ** }\end{array}$ & 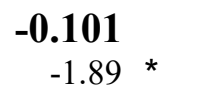 & $\begin{array}{r}-\mathbf{0 . 0 8 7} \\
-1.68\end{array}$ \\
\hline$\Delta D e p r_{i, t}$ & + & $\begin{array}{r}1.124 \\
3.69\end{array}$ *** & $\begin{array}{l}1.059 \\
3.43 * * *\end{array}$ & $\begin{array}{l}1.141 \\
3.30 * * *\end{array}$ & $\begin{array}{l}\mathbf{1 . 2 6 9} \\
3.56^{* * *}\end{array}$ \\
\hline$\Delta O$ therEx $x_{i, t}$ & + & $\begin{array}{r}1.014 \\
38.45\end{array}$ *** & $\begin{array}{c}\mathbf{1 . 0 1 4} \\
37.61^{* * *}\end{array}$ & $\begin{array}{r}\mathbf{0 . 9 7 0} \\
30.08 \quad \text { *** }\end{array}$ & $\begin{array}{l}\mathbf{1 . 0 0 3} \\
29.76 \text { *** }\end{array}$ \\
\hline$\Delta O p E x_{i, t-1}$ & $?$ & & $\begin{array}{r}-\mathbf{- 0 . 0 3 6} \\
-1.44 \text { ** }\end{array}$ & & $\begin{array}{r}\mathbf{0 . 0 3 9} \\
0.95\end{array}$ \\
\hline$\Delta O p E x_{i, t+1}$ & $?$ & & $\begin{array}{r}\mathbf{0 . 0 1 0} \\
0.31\end{array}$ & & $\begin{array}{r}\mathbf{0 . 0 4 4} \\
1.21\end{array}$ \\
\hline $\boldsymbol{R}_{i, t}$ & ? & & & $\begin{array}{r}-\mathbf{0 . 0 2 2} \\
-1.08\end{array}$ & $\begin{array}{r}-\mathbf{0 . 0 3 6} \\
-1.73 \text { * }\end{array}$ \\
\hline$R . \Delta D e p r_{i, t}$ & + & & & $\begin{array}{r}-\mathbf{0 . 3 1 7} \\
-0.24\end{array}$ & $\begin{array}{r}-\mathbf{0 . 1 2 0} \\
-0.09\end{array}$ \\
\hline R.AOtherEx $x_{i, t}$ & + & & & $\begin{array}{r}\mathbf{0 . 1 2 5} \\
1.92 \text { * }\end{array}$ & $\begin{array}{r}\mathbf{0 . 0 3 3} \\
0.46\end{array}$ \\
\hline$R . \Delta O p E x_{i, t-1}$ & $?$ & & & & $\begin{array}{r}-\mathbf{0 . 1 3 5} \\
-2.39 \text { ** }\end{array}$ \\
\hline$R . \Delta O p E x_{i, t+1}$ & $?$ & & & & $\begin{array}{r}-\mathbf{0 . 1 4 1} \\
1.82\end{array}$ \\
\hline $\operatorname{IFRS}_{i, t}$ & $?$ & $\begin{array}{r}-\mathbf{0 . 0 3 1} \\
-1.07\end{array}$ & $\begin{array}{r}\mathbf{0 . 0 3 0} \\
1.02\end{array}$ & $\begin{array}{r}\mathbf{0 . 0 4 7} \\
-1.47\end{array}$ & $\begin{array}{r}-\mathbf{0 . 0 5 1} \\
-1.63\end{array}$ \\
\hline $\boldsymbol{R} \boldsymbol{I F R S}_{i, t+1}$ & ? & & & $\begin{array}{r}\mathbf{0 . 0 1 9} \\
0.87\end{array}$ & $\begin{array}{r}\mathbf{0 . 0 2 2} \\
0.99\end{array}$ \\
\hline \multicolumn{2}{|c|}{ PAIRID dummies included } & yes & yes & yes & yes \\
\hline$R^{2}$ & & 0.938 & 0.939 & 0.940 & 0.943 \\
\hline$N$ & & 154 & 154 & 154 & 154 \\
\hline
\end{tabular}


TABLE 6: (CONTINUED)

\section{Notes:}

${ }^{*},{ }^{* *},{ }^{* *}$ indicate significant at the 10,5 , and 1 percent levels, respectively.

The dependent variable is $\Delta R e v_{i, t}$.

See table 5 for variable definitions. 